\title{
Malwina Mus
}

Uniwersytet Jagielloński

\section{Od włodarza do uciekiniera - \\ konstruowana $w$ relacji $z$ miastem tożsamość poetycka Marcina Świetlickiego i jej przemiany}

O Marcinie Świetlickim trudno dziś myśleć uyłącznie jako o autorze powieści i poezji. Udzielając się w wiclu plaszczyznach (literat, wokalista zespolu rockowego, rysownik, dziennikarz, aktor?, performer?), kwestionuje on granice pomiędzy poszczególnymi rolami, a także między kreacją a życiem. Jednym z. motywów, który sytuuje się na przecięciu tych tendencji i spaja poszczególne plaszcryzny aktymności (kwestionując tym samym granicę pomięday życiem a sztuką oraz wytyczając granicę - Kraków contra pozostała część świata'), jest miasto. Obranie perspektywy miejskiej pozwala więc na całościowy ogląd działalności artysty. Relacja między Marcinem Świetlickim (jako teoretyčną figurą będącą wypadkową poszczególnych podmiotów twórczych oraz ræcçywistej osoby) a Krakowem jest szalenie ambiwalentna, powstaje w napięciu między dośviadczeniem tożsamości a różności, rozbieżności. Każdorazowa konfrontacja "ymaga

To chyba najbardøiej aclekwatne określenic - w świecie literackim Świetlickiego istnieje przestrzeń poza Krakowem, ale na zasadzie „po\%ostalości”, „reštki”. Kraków šczelnie wrpelnia calą perspektụę dostępną podmiotowi tej twórčości. 
od podmiotu samookreślenia, eksponuje pewne jego cechy składające się na koherentny, choć zmieniający się w czasie portret: włodarza, rezydenta, w końcu uciekiniera. Motyw zainicjowany manifestacyjną frazą: „Któregoś dnia to miasto będzie należeć do mnie"? stanowi leitmotiv całej twórczości autora Zimnych Krajów i - co pewien czas - domaga się gruntownej rewizji. W niniejszym artykule poddam analizie kolejne wersje wiersza Opluty (37 uierszy o wódce i papierosach - 1996 r., Nieczyn$n y-2003$ r.), jego muzyczne realizacje związane ze zmianą tekstu (Ogród koncentracyjny - 1993 r., Cacy Cacy Fleischmaschine - 1996 r., Tradycyjne Polskie Pieśni Wielkanocne [Czarne Ciasteczka] - 2002 r., Las Putas Melancholicas - 2005 r.), a także zawierający się w ostatnim tomie Świetlickiego utwór Gotham (wraz z dwoma wariantami z plyty Sromota), stanowiący - jak się wydaje - domknięcie rozpisanej na kilkanaście lat historii.

Punktem odniesienia dla wszystkich kolejnych wariantów jest wiersz pt. Opluty pochodzący z trzeciego zbioru poety i - w niezmienionej wersji - slużący za tekst utworu z debiutanckiej plyty Świetlików's. Tytul piosenki został rozszerzony o adnotację: „stara kultowa wersja” i umieszczoną w nawiasie liczbę 44. To ważne sygnaly. Pierwszy wskazuje na szczególny status utworu, pozwalający zaliczyć go do grupy wierszy ${ }^{4}$, które proponuję nazzwá reakcyjnymi. Podejmują one szczególnie ważne dla podmiotu tej twórczości tematy lub ustalają specyficzną konwencję wypowiedzi, za pomocą której w przestrzeni kolejnych tomików można opowiedzieć o nowych sprawach. Utwory takie, rozsiane po różnych „książkach z wierszami” i płytach, tworzą ponad poszczególnymi wydawnictwami cykle ${ }^{5}$ - wzajemnie się do siebie odnoszą, komentują,

M. Świetlicki, Opluty, [w:] te ṅ̀e, Wicrsze, Kraków 2011, s. 150-151.

Świetliki, [CD) Ogrod koncentracyjn, Music Corner, 1993.

- Inne pra.klady to chociazby: Polska ([Dlaczego twój niepokój... ]), Odciski, Brudna woda, Jedna linijka przeciw (z wariantami: noc; państuu, tobie), M - (z rozwinięciami: czarny poniedzialek, $M-M-M$, morderca, morderstwo, między duudziestq drugq a czwartq nad ranem, polowa stycznia, w podróż, w sierpniu, w styczniu) itp.

; Analiza cyklu dotyçącego utworu Odciski i æwiązanych z nim przemian medialnych (wiersz, piosenka na plycie, wykonanie koncertowe, teatr itd.) zob. M. Mus, Wierszo-piosenki i spektaklo-koncerty' - medialne zawirowania w twórczości Marcina Śuietlickiego, 
weryfikują uprzednio wyrażone stanowiska i poglądy. Stąd określenie "reakcyjne" - powstają w reakcji na zmianę, nie aspirują do utrafienia w uniwersalną prawdę, ale relacjonują przemiany - zewnętrzne (w wierszach dotyczących spraw spolecznych, politycznych itd.) i wewnętrzne (w liryce osobistej). Najczęściej jednak oba te porządki mieszają się ze sobą, czego przykładem jest Opluty. „Stara kultowa wersja” przedstawia więc punkt wyjścia i wskazuje na jego nietrwalość, otwierając perspektywę nowych, zaktualizowanych wariantów.

Następującą tuż po wlaściwym tytule liczbę 44 można potraktować jako znacznik linii komunikacyjnej, wytyczający jeden z elementów morfologii miejskiej, jaki zarysowuje się w utworze: „Kraków i Nowa Huta, Sodoma z Gomorą / z Sodomy do Gomory jedzie się tramwajem" (w rzeczyıvistości linia nr 4 lączy wspomnianą dzielnicę z centrum Krakowa ${ }^{6}$ ). Podmiot wiersza jest blisko tkanki miasta - nie jeździ, a chodzi po śródmiejskim trakcie: „Planty, Szewska, Rynek [...], Rynek, Szewska, Planty”. Całości tej schematycznej mapy dopelnia Wisla - jedyny wentyl w hermetycznym miejskim kręgu, za pomocą którego nadejść ma „nowe”. Topografia Krakowa staje się metaforą zamknięcia, tradycjonalizmu, mieszczańskiego porządku (obraz skonstruowany na zasadzie negatywu cech wprowadzonych w wierszu przez. motyw statku pirackiego). W tym, jak można mniemać, niekorzystnym kontekście, bohater lokowany jest centralnie - porusza się w obrębie ścisłego centrum, egzekucji dokona na samym środku Rynku. Z jednej strony jest to przestrzenny obraz typowego dla Świetlickiego egocentryzmu ${ }^{7}, \mathrm{z}$ drugiej - symboliczne utożsamienie $\mathrm{z}$ miastem, bycie blisko jego cech relewantnych, blisko - jeśli trzymać się metafory organicznej serca miasta. Niczym uśpiony wirus, bohater krąży po glównej aorcie, by stopniowo oslabiać odporność i wreszcie przypuścić atak na micjski ustrój.

„Ruch Literacki” 2013, ж.6 (321), s. 689-700 , [online] http://dx.doi.org/10.2478/ v10273-012-0094-\%.

- Trakcja jako taka jest szczególnie upodobana przez krakowskich pisarzy przclomu lat 80. i 90. Linią nr 4 jedzie również Gustaw - bohater Spisu cudzolożnic Jerzego Pilcha, w jednej ze znaczących scen powieści.

Zob. P. Śliwiński, Praypisy do Świetlickiego, [w:] te nże, Świat na brudno. Szkice o poezji i krytyce, Wars/awa 2002, s. 232-244. 
Tytulowa liczba 44 może mieć naturalnie takje inne znaczenie, nawiązujące do wielkiej romantycznej tradycji oczekiwania na polskiego męża opatrznościowego. Do takiej interpretacji zachęcają figlarne gry Świetlickiego (realnej osoby) z własną tożsamością, przejawiające się w licznych wypowiedziach, takich jak ta: „Urodzilem się w tym samym dniu co Adam Mickiewicz i to 44 też na mnie trochę świeci. [...] Ja jestem tylko bękartem Mickiewicza" . W subtelnej sugestii kryje się zatem odważna autoprezentacja pogę̨iająca jeszcze radykalizm wierszowej zapowiedzi: „I zapytają: / - Który to Świetlicki? / A ja wtedy stanę / na samym środku Rynku/i będę wskazywać: / - Tego. Tego. Tego. / Tego. Tego. Tamtą / Tego sprzątnąć / Tamtą skasować. / Tego. Tamtą. WSZYSTKICH!". Archetypicznie przywolane w utworze Sodoma i Gomora skłaniają, by podjąc trop biblijny, realizujący się również w figurze utajonego, czasowo znoszącego upokorzenia władcy miasta. Jeśli tak o nim pomyśleć, tytułowy Opluty przypomina nieco Chrystusa. „Napluli mi na plecy, nic o tym nie wiem”świadomość nie rodzi potrzeby zmian, nie wynika $z$ empirycznych doświadczeń, lecz w plaszczyźnie symbolicznej opisuje charakter tego miasta, jego immanentną cechę prowokującą do snucia podejrzeń o znieważanie, brak szacunku. Wejście $w$ miasto oznacza akceptację reguł $w$ nim panujących, przyjęcie wyzwania. W przypadku podmiotu - oznacza nieustanne nadstawianie policzków, zgodę na udrękę, ale też zakłada rewanż na tych samych zasadach, gdy zmieni się koniunktura i miasto ulegnie wplywom nowych, barbarzyńskich zjawisk (reprezentowanych tu przez najazd piratów). Rewolucja jest zatem kwestią czasu i jedynym rozwiązaniem. Tylko tak dojść może do symbolicznej śmierci, zmartwychwstania i sprawiedliwego sądu, na którego czele stanie bohater. Choć w wierszu brakuje wyraźnych tropów pasyjnych, mechanizm objęcia władzy nad miastem wydaje się opierać właśnie na takiej złośliwie mesjańskiej logice, która - jak pokaż̨̨ w dalszej części - zostaje uruchomiona również w utworze Gotham.

S. Bereś,Jestem bękartem Mickieuicza - rozmowa z Marcinem Świetlickim, http://kultura.dziennik.pl/artvkuly/195729,jestem-bekartem-mickiewicza.html (20.03.2014). Tam równiez więcej o symbolice liçby 44: „Ostatnio wsarstkie moje ksiąiki mialy 44 wiersze. Pomyślałem, że to znakomita liczba. Ksiąika z. 44 wierszami juz nie jest zupełnie cienką, niepowaziną książeczką". 
Kilka lat po wydawniczym debiucie Świetlików, na albumie Cacy Cacy Fleischmaschine (1996 r.) pojawia się Opluty 2 - utwór korygujący przedstawioną wcześniej wizję objęcia władzy nad miastem. Kapitulacja zostaje zobrazowana poprzez rekonfigurację elementów w przestrzeni miejskiej - podmiot stracił w niej swoją centralną pozycję, wycofał się na peryferyjny trakt, poza punktami orientacyjnymi miasta, poza jego glównymi wewnętrznymi napięciami (relacja Sodomy i Gomory, centrum i Nowej Huty). Pomiędzy podmiotem a miastem pojawia się dystans, somatycznie polączone dwa systemy przestają okazywać sobie bliskość spełniającą się dotąd w „chodzeniu po mieście”. Eksplorowanie przestrzeni zostaje więc zapośredniczone poprzez taksówkę i jest sporo teatralnego przerysowania w wyznaniu podmiotu: „Ja juz nie chodzę, ja jeżdżę". Brzmi to jak zdrada czy porzucenie (samo pragnienic, by posiąść obiekt, ma coś z erotycznej fascynacji, zatem optyka spojrzenia na miasto i na kobietę jest u Świetlickiego pod pewnymi względami podobna) i tak też się kończy - rozstaniem: „Proszę na mnie nie patrzeć, $[\ldots]$ proszę do mnie nie mówić, ja wychodzę". Odejście wymaga przemieszczenia na mapie i bazuje na charakterystycznym dla krakowian przeświadczeniu, że wlaściwe miasto ogranicza się do centrum. Pojawiająca się tu nazava dzielnicy Borek Fałęcki - lingwistycznie zupełnie niepoetycka i (jeśli potraktować ją doslownic) nie-miejska, topograficznie zaś usytuowana na obrzeżach Krakowa - budzi rozbawienie. W polu widzenia podmiotu wciąż jednak pozostaje centrum - przestrzeń swoistości miasta, scena zajęta przez innych aktorów. Wymienieni tu Grzegorz Turnau, Zbigniew Preisner i ksiądz. Tischner nie stanowią, jak się wydaje, właściwego celu ataku'. Nie o nich chodzi, a o mechanizmy rządzące w środowisku (skoro w mieście, to w świecie), które wyniosly ich na piedestal. Naznviska postaci, ich status, dzialalność, jaką uprawiają - uświęconc prze\% miasto, stanowią emblemat jego charakteru, potwierdzają zdiagnozowaną

W realizacji koncertowej "yliczenie "ypelniane jest różnymi nanviskami lub naniani grup, w zależności od tego, kto aktualnie święci triumfy w krakowskim światku. Dla prọkladu, naæia zespolu Mvslovitz pojawiała się w Oplutym wówčas, gdy grupa nagrala drugą wersję popularnej piosenki pt. Kraków, » gościnnım udzialem Marka Grechutv: 
w poprzedniej wersji Oplutego hermetyczność tego miejsca, tradycjonalizm, skostnienie. Również egoizm czy próżność - wymienieni twórcy nic reprezentują nurtu rewizyjnego, nie kwestionują status quo, są piewcami miejsca, gwarantami trwania jego konserwatywnych wartości, które legitymizują swoją działalnością. Przeczuwana w „starej kultowej wersji” rewolucja nie nadchodzi.

Kwitujące pojedynek tych dwóch egotycznych podmiotowości (bohatera i miasta), powracające w utworze jak mantra "pomyliłem się", nie jest pokornym przyznaniem się do blędu, ale raczej uszczypliwym komentarzem pod adresem miasta, wskazującym na rozczarowanie, zawód pokładanych w nim nadziei. Fraza zapowiada wycofanie się podmiotu z zewnętrznej aktywności i emigrację wewnętrzną, zwrócenie się ku uporczywej autoanalizie, ku znośnej wersji rzeczywistości. Pojawiająca się w zakończeniu diagnoza: „To miasto jest wszędzie” wymusza kapitulację wobec świata, ale też zdradza, że pod przykrywką bojów z Krakowem ukryte są batalie, jakie podmiot tych utworów toczy z calą otaczającą go rzeczywistością, jawiącą się mu jako tlamszący go moloch.

Przebłysk melancholii pojawia się w kolejnej wersji Oplutego, z. adnotacją „(74)”. Utwór pochodzi z tomu Nieczynny (2003 r.); w tylko nieznacznie zmienionej formie pojawil siç on również na plycie Tradycyjne Polskie Pieśni Wielkanocne (2002 r.) projcktu muzycznego Czarne Ciasteczka, 7. którym wspólpracuje Świetlicki. Co szczególnie istotne dla zrozumienia relacji podmiot-miasto, pojawiające się tu sentymentalne wspomnienie: „To miasto kiedyś należalo do mnie. / To miasto kiedyś było moje"10 oddaje, jak sądzę, nie tyle relację wladశৈy i podrzędności, co tożsamości. Kiedyś identyfikowalem się z tym miastem - wydaje się mówić podmiot i wskaz̧wać na sytuację przedstawioną w pierwszej wersji Oplutego (kiedy bliski æiiązek z organizmem miejskim byl podtrzymywany m.in. poprzez. „chodzenie po centrum"), kicdy podmiot snuł plany przejęcia władzy nad miastem, nie tylko $z$ wewnętrznych, egocentrycznych pobudek, alc

11' Crarne Ciastecrka, Opluty 74, [CDI Tradycyjne Polskie Picśni Wiclkanocne, Biuro Literackie 2002. Wersja wierszowa nie jest tak dobitna: „Któregoś dnia to miasto nalèało do mnie" (M. Świetlicki, Opluty (74), [w:] te nґ.c, Wicrsze, s. 368). 
też z troski o to, co na zewnątrz. Staral się doprowadzić do uzgodnienia tych dwóch zajmujących go przestrzeni. Z perspektywy czasu (kolejnych wersji) okazuje się, że na tej trosce właśnie opiera się tematyzowane w wierszach ,posiadanie" miasta, bycie jego włodarzem.

Jest to newralgiczny moment calego cyklu, miejsce, w którym bezpowrotnie zamknięta zostaje droga do komunii z miastem. Kolejna rekonfiguracja przestrzenna pogłębia rozziew między podmiotem i miejscem, w którym żyje. Domeną tego drugiego staje się ruch, zmiana, balansowanie między nowym i starym ("święci mędrcy i chlopcy z generacji NIC"॥ przejmujący scenę miasta), podczas gdy podmiot zajmuje nieruchomą pozycję poza glówną przestrzenią, z której przygląda się życiu i wyciąga wnioski. To perspektywa demiurgiczna (metaświadomość dostrzegająca konsekwentny upadek miasta), choć wciąż zainfekowana ludzką mentalnością. Opozycja statecznego bohatera i dynamicznej metropolii jest odwróceniem pierwotnego porządku - dotąd miasto trwalo nicwzruszone, a bohater po nim chodzil, przemieszczał się, snuł plany; micjsce, jakie zajmował w przestrzeni, odpowiadalo jego nastawieniu wobec miasta. Jedynym ruchem, na jaki pozwala sobie bohater w nowej wersji Oplutego, jest gest odstąpienia, czyli rezygnacji, ostatecznej kapitulacji. W wyznaniu: „Ja już nie chodzę, ja leżę... / patrzę na sufit. / [...] A teraz leżę w domu na przedmieściu" dopelnia się postępujące od pewnego czasu rozdwojenie perspektyw. Pozycja, w jakiej znajduje się bohater, symbolizuje upadek

1 Pobläliwe określenie „chłopcy \% generacji NIC” \% pewnością odnosi się do zespolu Cool Kids of Death, który zadebiutowal wydawniço w 2002 roku. Na plycie pt. Cool Kids of Death tytulowa piosenka przedstawia zespól jako niewinnych chlopców \% karabinami, zaś utwór Generucja Nic ma formę manifestu generacyjnego, podobnie jak felieton pod tym samym tytułem, opublikowany w „Gazecie Wyborcac”” prze\% Kube Wandachowiča - basistę grupy. Tekst sprowokowal dyskusję o pokoleniu ówczesnych 20-latków, a zespól zyskal slawę czolowych buntowników polskiej sceny alternatiwnej - to wstarczająco wiele powodów; by Świetlicki wspomnial o nich w niechlubnım fragmencie Opluteyo, gdzie CKOD zajęlo miejsce Gr»egor/a Turnaua, zespolu Mysilovite itd. Co svmptomatycene, grupa Cool Kids of Death zawsze mocno podkreślala swoje lódzkie pochodzenic, z Krakowem zaś nie miala wiele wspólnego, a wlaśnie to kryterium decydowalo o wybor „miasto jest wscędzie" ostatec znie nabrala swojej mocy - miasto Swietlickiego to ju: nie geografičny Kraków; ale uniwersalny model relacji podmiotu z rzecṇwistością. 
(w porządku wertykalnym) i marginalizację (w porządku horyzontalnym), tymczasem z punktu widzenia bohatera - to miasto upada. Symptomy schyłku metropolii upatrywane są w zjawiskach obiektywnie pozytywnych: zatrudnienia w firmach, rozwój infrastruktury. Okazuje się, że problem tkwi w samym podmiocie, w jego anachroniczności, nieżyciowości, nadwrażliwości, w nieatrakcyjnych dla ogólu preferencjach. Wzięcie miasta w posiadanie nie pomoże zalagodzić tych rozbieżności, wnętrze i zewnętrze podmiotu jest skazane na konflikt: „to miasto nie będzie moje, bo już było. // I to nie było przyjemne".

Wiersze należące do cyklu wyrażaly dotąd zarzut wobec świata. W tym miejscu następuje jednak zmiana - utwory zaczynają sugerować, by krytycznie przyjrzeć się podmiotowości wygrażającej miastu. Tylko w jej ironiczno-sceptycznej optyce miasto dzieli się na „świętych starców” i „chłopców z generacji NIC”, powiększa się o „multikino” - symbol konsumpcji i profanacji sztuki oraz cmentarz - symbol śmierci. W stosunku do miasta to perspektywa z pewnością przesadzona, ale jako świadectwo charakteru bohatera - interesująca, a może nawet pociągająca.

Opluty z Las putas melancholicas (2005 r.) jest w zasadzie tematycznym rozwinięciem wątków zapoczątkowanych w poprzednim utworze i - ponieważ rozpoczyna się parafrazą „starej kultowej wersji” („Któregoś dnia to miasto należało do mnie"12) - tworzy klamrę dla całego cyklu. Przestrzenne wyalienowanie ostatecznie przestaje tu pełnić funkcję ochronną dla podmiotu. Leżąc nieruchomo na uboczu, obserwuje ze zgrozą, jak rozrastające się macki miasta zaczynają sięgać jego terenu („Z jednej strony supermarket przybliża się do mnie / Rozbudowywowuje się / z drugiej strony cmentarz zbliża się do mnie / grób po grobie / grób po grobie. / Normalnie."). Tkanka miasta już niebawem pochłonie podmiot, wykona wyrok na niesubordynowanym i wyalienowanym obywatelu. Przemiany dynamicznego (jak zostało wykazane) miejsca ukształtowały przestrzeń, w której nie ma już miejsca na bohatera, nie ma mowy o tożsamości. Podmiot zostaje zepchnięty, a następnie wchlonięty, przygnieciony przez.

1: Świetliki, Opluty, [CD] Las putas melanchólicas, Universal Music Polska, 2005. 
miasto-molocha. Przyjmuje to z dystansem i mantryczno-katolickim spokojem, uwydatnionym jeszcze linią melodyczną. Powtarzająca się fraza: „Tak, Panie Jezu, tak / Normalnie” nasuwa skojarzenie z pasyjnym wyznaniem: „Wykonalo się" - w ten sposób dopelnila się historia obcowania podmiotu w świecie, w mieście, którego był władcą, ale - pozostając w stylistyce biblijnej - nie został rozpoznany. Staranie, którego finał od początku był zatem znany (jeśli potraktować je jako ponowoczesną historię zbawienia), nie otwiera jednak perspektywy metafizycznej dla żadnej ze stron. „Pan Jezus” przywolywany jest tu nieco ironicznie, raczej jako postać rodem z folkloru miasta, uzupełniająca obraz stworzony przez wyznawców Hare Kryszna oraz uczestników „wszechgejowskiej parady”. Miasto dalej żyje swoim rytmem, zaś bohater zupełnie się od niego odkleja, odcina, tworząc własną, zamkniętą, wyizolowaną przestrzeń. „Ja już nie chodzę / Ja już nie jeżdżę / Ja leżę. W sufit patrzę" - to przybranie pozycji wyjściowej do sytuacji z wiersza *** [Cały pokój jest obwieszony Marcinami. . . ] oznacza emigrację wewnętrzną i ucieczkę w uporczywą wiwisekcję.

\section{Epilog}

Wątki realizowane na przestrzeni kilkunastu lat w kolejnych wersjach utworu Opluty znalazły swoje rozwinięcie i zwieńczenie w wierszu Gotham $\mathrm{z}$ tomiku Jeden oraz piosence pod tym samym tytułem funkcjonującej w dwóch wykonaniach (Marcina Świetlickiego i Bogusława Lindy) na plycie Sromota. Utwór muzyczny zawiera jednak pewne znaczące przesunięcia w treści.

Nazwa „Gotham” używana wobec wciąz tego samego miejsca - Krakowa, odnosi się do Gotham City - czçsto pojawiającego się określenia Nowego Jorku, zaanektowanego przez twórców komiksów i najbardziej znanego z opowieści o Batmanic. (Pop)kulturowy charakter tego micjsca na przestrzeni lat ewoluowal, ostatecznie utrwalając się jako sygnatura terenu mrocznego, strasznego, nicbezpiecznego, którego mieszkańcy potrzebują ochrony postaci obdarzonej nadludzką mocą. W tej roli Świetlicki jawnie obsadza podmiot/bohatera swoich utworów (szčzególnie wyraźnie 
widać to na przykładzie wersji piosenkowej: „Mój pojazd rdzewieje na parkingu" - gdzie mowa o jednym z ważniejszych akcesoriów Batmana), ironicznie grając również z wlasną - wychodzącą poza figurę literacką kreacją artystyczną (mistrz, bohater kryminałów Świetlickiego, to dziecięcy superbohater doby PRL-u; powraca status Marcina Świetlickiego jako bytu literacko-empirycznego). Trawestacja motywu popkulturowego herosa dochodzi do apogeum (kuriozum?) w przypadku wersji tej piosenki śpiewanej przez Bogusława Lindę - którego kreacje aktorskie wcieliły polski archetyp superbohatera. I choć w piosenkach właśnie ten trop zostaje szczególnie wyróżniony, podtytuł drugiej z nich otwiera możliwość dość zaskakującej interpretacji.

Gotham Pana B - inicjal można rozwijać jako imię Lindy, ale też inaczej: jako „Gotham Pana Boga” (tym bardziej, że na plycie ${ }^{13}$ poprzedza tę piosenkę utwór Piosenka Pana Boga). Warto zatem powrócić do utworu wierszowego i zwrócić uwagę na personifikację, jakiej podlega zarówno motel Krak - symbol dawnego porządku, jak i samo miasto (ono myśli, ono myli się, ono też-korzystając z wolnej woli - nie chce już pomocy). Należy je zatem traktować jako pars pro toto spoleczności grzeszącej wobec (super)bohatera pychą, rezygnującej z jego pomocy, ignorującej jego postać i kompetencje. Momentem granicznym, w którym bohater sam porzuca swoją opiekuńczą misję, jest dopiero „śmierć motelu Krak” - wówczas podmiot opuszcza miasto, przepowiada jego upadek i ciska w jego stronę przekleństwa. Jakże podobny motyw odnaleźć można w Księdze Rodzaju, w której Bóg postanawia zachować miasto ze względu na garstkę sprawiedliwych (tu: motel) ${ }^{14}$. Rozczarowany Batman miesza się w podmiocie tego wiersza z. figurą znudzonego Chrystusa i opuszcza miasto, osiedlając się w - jak wiadomo z pozostalych wierszy zbioru, a także medialnych wypowiedzi autora - w rejonie położonym poza centrum: z Małego Rynku przenosi się w okolice Kazimierza.

1) Swietliki, [CD] Sromota, Karrot Komando 2013.

it Warto zauważć, ie historia biblijna doticn Sodomy i Gomory - miast (funkcjonujących w kulturze jako symbole roxią̧łości i rozpusty), z którymi w pierwszcj wersji Oplutego zestawione zostaly Kraków i Nowa Huta. 
Analiza calego cyklu wierszy o relacji między podmiotem artystycznym Marcina Świetlickiego a miastem charakteryzuje obie te figury, ostatecznie więcej mówiąc jednak o tytulowym Oplutym. Należy nadmienić, że postawy wlodarza i uciekiniera - zawarte w tytule mojego artykułu - choć wytyczają glówne tendencje, domagają się uczynienia szeregu obostrzeń. Podmiot jedynie aspiruje do tego, by posiąść miasto, co ostatecznie nie udaje mu się (klęska byla od początku wpisana w scenariusz tych batalii?). Sam akt posiadania wyzuty jest z relacji władzy i podporządkowania, należy go raczej rozumieć jako quasi-milosną potrzebę utożsamienia, uzgodnienia tego, co wewnętrzne i zewnętrzne. To jednak okazuje się niemożliwe i na plan pierwszy wysuwają się tu przyczyny, dla których - mimo starań - do symbolicznej komunii dojść nie może. W tym awarciu dwóch podmiotów: bohatera i miasta, uwidaczniają się ich konstytutywne cechy. Domeną tego drugiego jest nieustanna przemiana $\mathrm{i}$ - by tak rzec - beztroska. Podmiot zaś, konfrontując się z miastem, coraz silniej osuwa się w głąb siebie, aż do momentu, w którym odbiorca uświadamia sobie, że prezentowana mu wizja przestrzeni jest projekcją odczuć bohatera.

Puentą opowieści o relacji podmiotu i miasta jest więc alienacja bohatera i zwrot ku własnemu wnętrzu. W ten sposób da się tlumaczyć egotyzm Świetlickiego - mechanizm wtórny, nabyty w konfrontacji z rzeczywistością. Status uciekiniera miesza się tu z sytuacją wyrzutka, a calość zostaje uwikłana w motywy biblijne („Przyszedłem w imieniu Ojca mojego a nie przyjęliście mnie" - Ewangelia wg św: Jana [5,43]) i opisywana w perspektywie skomplikowanych relacji między Bogiem a ludzkością. Konstruowanie tożsamości w relacji z miastem okazuje się niespodziewanie uzupelniać (pra)historię fundującą tę tożsamość, zawartą w kilku pierwszych wierszach debiutanckiego tomu Świetlickiego, szczególnic iv utworze Wstep $^{15}$.

is Zob. T. Kunz, Postępy ciemności, [w:] Mistrz świato. Szkice o twórczosci Marcina Świetlickiego, red. P. Śliwiński, Poznań 2011. 


\section{Abstract \\ From steward to fugitive - the city and Marcin Świetlicki's poetic identity's changes}

An analysis of recorded and versed versions of Opluty and its thematic continuations: a poem and two songs titled Gotham. These pieces pan out into a cycle about relations between Marcin Świetlicki's lyrical I and the city. Its elements show an evolution of relations: dynamics of the city and change of the hero's status - from an anticipated ruler and the people's messiah he becomes an outcast and a fugitive. His escape is an internal emigration, which leads to Swietlicki's typical egotism. The cycle is created as a biblical salvation scheme, relations between the hero and the city resemble complicated relations between God and humanity. 